\title{
Sources of Resistance to Sorghum Grain Molds
}

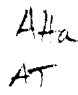

R. BANDYOPADHYAY. Plant Pathologist, I.. K. MUGHOGHO. Principal Plant Pathologist, and K. E. PRASADA RAO. Senior Botanist. International (rops Research Institute for the Semi-Arid Tropics (ICRISAT), Patancheru P.O.. Andhra Pradesh 502 324. India

\section{ABSTRACT}

Bandyopadhya!, R., Mughogho, I K... and Prasida Rau, K. F. 1988. Sorutess of resiotatce to sorghum grain mold. Plant Discase 72: 9(1)4-51)K

Selected actessions from the world collechon ol sorghum germ plism were systematically screctned in the field during the 19x(t-1985 rains seasons 10 identify wures of grain mold resistance. ( $)$ 26.564 accessiom indecellection, 7.132 that howered and matured during the rainy season at ICRISAI center wereened, and 1,5 h genetically diserse lines were selected as resistant. Al resistant atceations exo pt one had colored pericarp. However. 24 aceessions wilh colored pericarp had negligible enoues of tannin. and 14 of the 24 lacked the testit layer.

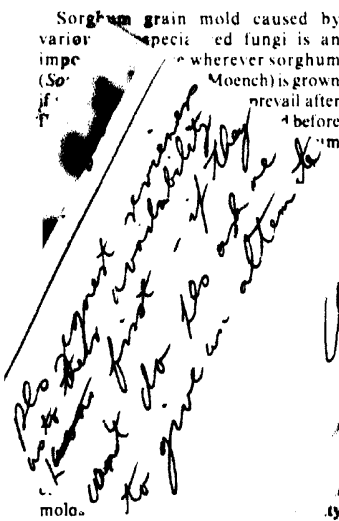

and quah.

make it unaces.

The only practis

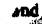

method for control of . A thin molds is the use of molto sesi"tant cultivars. The status of the for sources of grain mold resiet wee was reviewed in 1981 by Willy and Rao (14), who emphasized the do search for better sources of resistance. In 1980 . we began systematic screening of the world collection of sorghum germ plasm assembled at the Genetic Resources Unit (GRU) of the International Crops Research Institute for the Semi-Arid Tropics (ICRISAT). Patancheru. India.

Submitted as Journal Article 690 by the International Crops Research Institute for the Semi-Arid 1 ropies (ICRISAT).

Accepted for publication 23 September 1987.

- 1908 The American Phytopathological Society

\section{MATERIALS AND METHODS}

Selection of test material. Ficld experiments were conducted during the $198(-19 \times 5$ rainy seusons at ICRISAI Center. Because of the limited rainy season (June-October) and photoperiod sensitivity of sorghum at Patancheru, we screened only those accessions that - nwered and the grain before the 'the rainy 1 ison. We selected for haly tope accessions from the A. Fon that flower within Now ting in the rainy season

1

selections were based were obtained from the evaluation data recorded by GRII. The selected lines flowered before the first week of September. and their gruins matured during frequent rains in Seplember and Oetober.

Screening method and grain mold rating. The following screening method was used unless indicated otherwise. Trials were sown before the onset of the rainy season in the lirst half of June so that grain maturing stages coincided with periods of freyuent rainfall in September. The sorghum lines were classified into early (less than fodays to 50 \% flowering) and midium (h6-80 days to $50 \%$ flowering) maturity groups. Each maturity group was sown in a separate block to simplify data collection. The plots were sprinkled for $\mathrm{I} \mathrm{hr}$ in the morning if it did not rain the previous night and same morning, and for an additional hour in the evening if it did not rain throughout the day. Overhead sprinkler irrigation was provided from 
ering to grain maturity (black layer ation) and up to 2 wh later when icles were harvested. Susceptible ks of variable maturities were sown comparison. Flowering data were rded as days to $50 \%$ flowering when of the plants had $50 \%$ of the spikelets ering. Panicles were harvested 14 ; after maturity and threshed, and ns were evaluated for grain mold rity, called the threshed grain mold 18 (TGMR). This is an estimate of the entage of molded grain surface area is recorded on a 1-5 scale where $1=$ rold visible, $2=1-10 \%, 3=11-25 \%$. $26-50 \%$. and $5=$ more than $50 \%$ of grain surface molded. Germination tested at least I mo after harvest by bating 100 grains in petri dishes lined wet filter paper at $30 \mathrm{C}$

itial screening. Test lines were sown replicated $4 \mathrm{~m}$ row plots. Accessions TGMRs of up to 3 and with less than of the grain area covered by glumes : selected for further evaluation in inced screening trials.

dvanced sereening. Test lines were $\mathrm{n}$ in two 4-m row plots in a split-plot gn (two replications) with accessions ined to main plots and two inoculation treatments in subplots. Inocula of the major mold-causing fungi-- Fusarium moniliforme Sheld., $F$. pallidoroseum (Cooke) Sacc., and Curvularia lunata (Wakker) Boedijn-were separately multiplied on autoclaved sorghum grain for $10-14$ days at $30 \mathrm{C}$. Suspensions of spores and mycelium of the three fungi were prepared containing $1 \times 10^{6}$ spores of each fungus per milliliter. At the $50 \%$ flowering growth stage. 10 randomly selected panicles of one row in each plot were sprayed with the fungal suspension, tagged, and covered with kraft paper bags $(14 \times 6 \times 42 \mathrm{~cm})$ that were removed 7-10 days later. Ten panicles of the second row were tagged but not inoculated or bagged. TGMRs were recorded separately on the 20 tagged panicles, and a mean TGMR value for each inoculation treatment was calculated. Accessions with TGMRs of up to 3 and grain germination above $70 \%$ were repeatedly screened in subsequent years until 1985

Presence of testa. All resistant genotypes were examined to determine if they possessed a testa layer. Grains were cut transversely with a sharp scapel near the tip of the embryo toward the stylar end. Cavity slides were filled with $2 \%$ molten water agar, which was allowed to solidify. Then, three cut grains were pressed in the agar, which acted as a support so that the exposed grain surface faced upward parallel to the slide. The exposed grain surface was covered with a drop of immersion oil and examined for the testa layer at $200 \times$ magnification with epifluorescence optics of an Olympus fluorescence microscope equipped with HBO 200W mercury lamp, UG-I exciter filter, and a DM $400+$ L 420 dichoric mirror-cum-absorption filter.

Estimation of tannin content. The amount of tannin in mature grain was determined by the vanillin assay method, and the values were calculated by substracting the blank with catechin as a standard $(10)$. The results are reported as catechin equivalents (CE \%).

\section{RESULTS AND DISCUSSION}

We screened 7.132 accessions $(26.8 \%)$ of the world collection of sorghum germ plasm for resistance to grain mold and identified 156 accessions as resistant in repeated screenings for 2-6 yr during 1980-1985 (Tables 1 and 2). Grain mold pressure was high in all the years as

2. Country of origin, presence of testa. grain tannin content, days to $50 \%$ flowering, and threshed grain mold rating (TGMR) of sorghum lin d resistant to grain mold in field screening at ICRISAT Center. Patancheru. India, during 1980-1985 rainy seasons

\begin{tabular}{|c|c|c|c|c|c|c|c|}
\hline $\begin{array}{l}\text { saion } \\
\text { J. }\end{array}$ & Oripin & Race" & $\begin{array}{c}\text { Tenta } \\
\text { present (P) } \\
\text { or } \\
\text { absent (A) }\end{array}$ & $\begin{array}{l}\text { Grain } \\
\text { tannin } \\
\text { content } \\
\text { (CE \%) }\end{array}$ & $\begin{array}{l}\text { Number } \\
\text { of years } \\
\text { screened }\end{array}$ & $\begin{array}{c}\text { Deys } \\
\text { to so\% } \\
\text { nowering }\end{array}$ & TGMR' \\
\hline & Mexico & C & $\mathbf{P}$ & 3.6 & 5 & 62 & 2.3 \\
\hline & USA & C & $\mathbf{P}$ & 2.3 & 5 & 58 & 2.0 \\
\hline & USA & C & P & 1.4 & 5 & 52 & 2.6 \\
\hline & USA & $\mathrm{C}$ & p & 1.1 & 5 & 58 & 2.5 \\
\hline & USA & C & $\mathbf{P}$ & 1.8 & 5 & 60 & 2.0 \\
\hline & USA & C & p & 1.1 & 5 & 61 & 2.0 \\
\hline & USA & C & $\mathbf{p}$ & 3.3 & 5 & 56 & 2.2 \\
\hline & USA & C & $\mathrm{P}$ & 1.4 & 4 & 66 & 2.4 \\
\hline & China & KB & $\mathbf{P}$ & 1.3 & 3 & 50 & 2.8 \\
\hline & USA & C & $\mathbf{P}$ & 6.1 & 2 & 65 & 3.0 \\
\hline & Sudan & C & P & 0.2 & 6 & 78 & 2.2 \\
\hline & USA & C & P & 1.4 & 5 & 59 & 2.0 \\
\hline & USA & C & $\mathbf{p}$ & 1.3 & 5 & 56 & 2.0 \\
\hline & USA & c & $\mathbf{P}$ & 1.8 & 5 & 56 & 2.0 \\
\hline & Zimbabwe & C & $\mathbf{P}$ & 1.9 & 5 & 55 & 2.0 \\
\hline & Zimbabwe & C & $\mathbf{P}$ & 1.9 & 5 & 55 & 2.0 \\
\hline & South Africa & C & $\mathbf{P}$ & 1.4 & 6 & 53 & 2.0 \\
\hline & Zaire & C & $\mathbf{P}$ & 1.4 & 5 & 68 & 2.2 \\
\hline & Sudan & C & $\mathrm{P}$ & 1.3 & 6 & 71 & 2.3 \\
\hline & Taiwan & $\mathrm{DB}$ & $\mathbf{P}$ & 1.0 & 5 & 55 & 2.7 \\
\hline & Indin & C & $\mathbf{P}$ & 2.5 & 5 & 62 & 2.3 \\
\hline & India & CB & $\mathbf{P}$ & 2.4 & 4 & 58 & 2.5 \\
\hline & Indis & DC & $\mathbf{P}$ & 2.6 & 5 & 59 & 2.4 \\
\hline & Indin & C & $\mathbf{P}$ & 2.1 & 5 & 51 & 2.0 \\
\hline & Sudan & $\mathrm{CB}$ & $\mathbf{P}$ & 2.2 & 5 & 63 & 2.2 \\
\hline & Nigeria & C & P & 1.6 & 5 & 58 & 2.0 \\
\hline & & & & & & & wed on $n$ \\
\hline
\end{tabular}

icolor, $\mathrm{BC}=$ bicolor-caudatum, $\mathrm{C}=$ caudatum, $\mathrm{CB}=$ caudatum-bicolor, $\mathrm{D}=$ durra, $\mathrm{DB}=$ durra-bicolor, $\mathrm{DC}=$ durra-caudatum, $\mathrm{G}=$ guines,

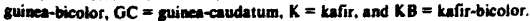

I baned on number of years tested.

I oa a 1-5 seale where $1=$ no mold and 5 = more than $50 \%$ of grain surface molded. Values are the maximum of the mean scores of 10 panicles $t$ inceulated and baged or not treated) recorded for any year of screening.

net available.

num grais moid rating for any year of screening. 


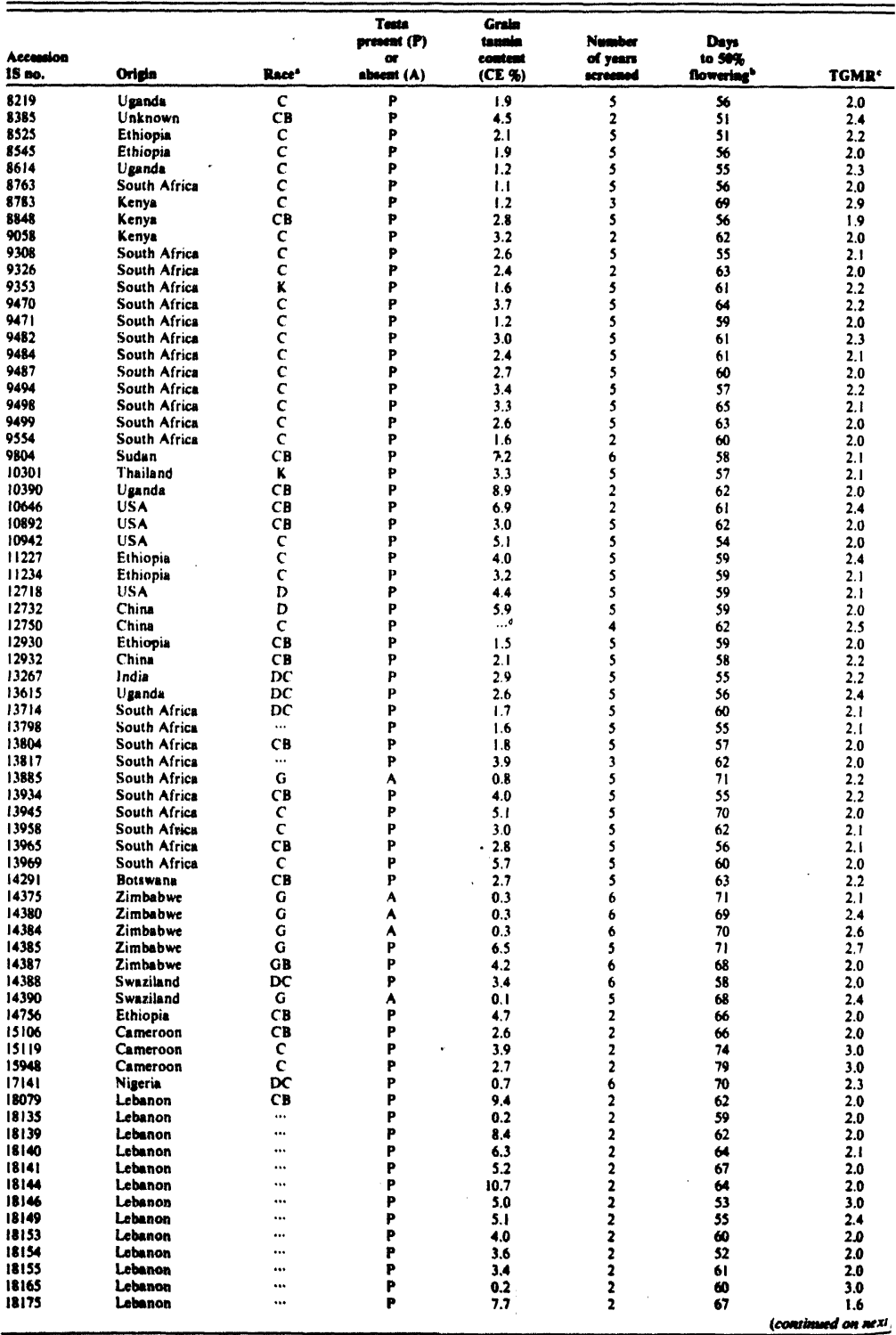




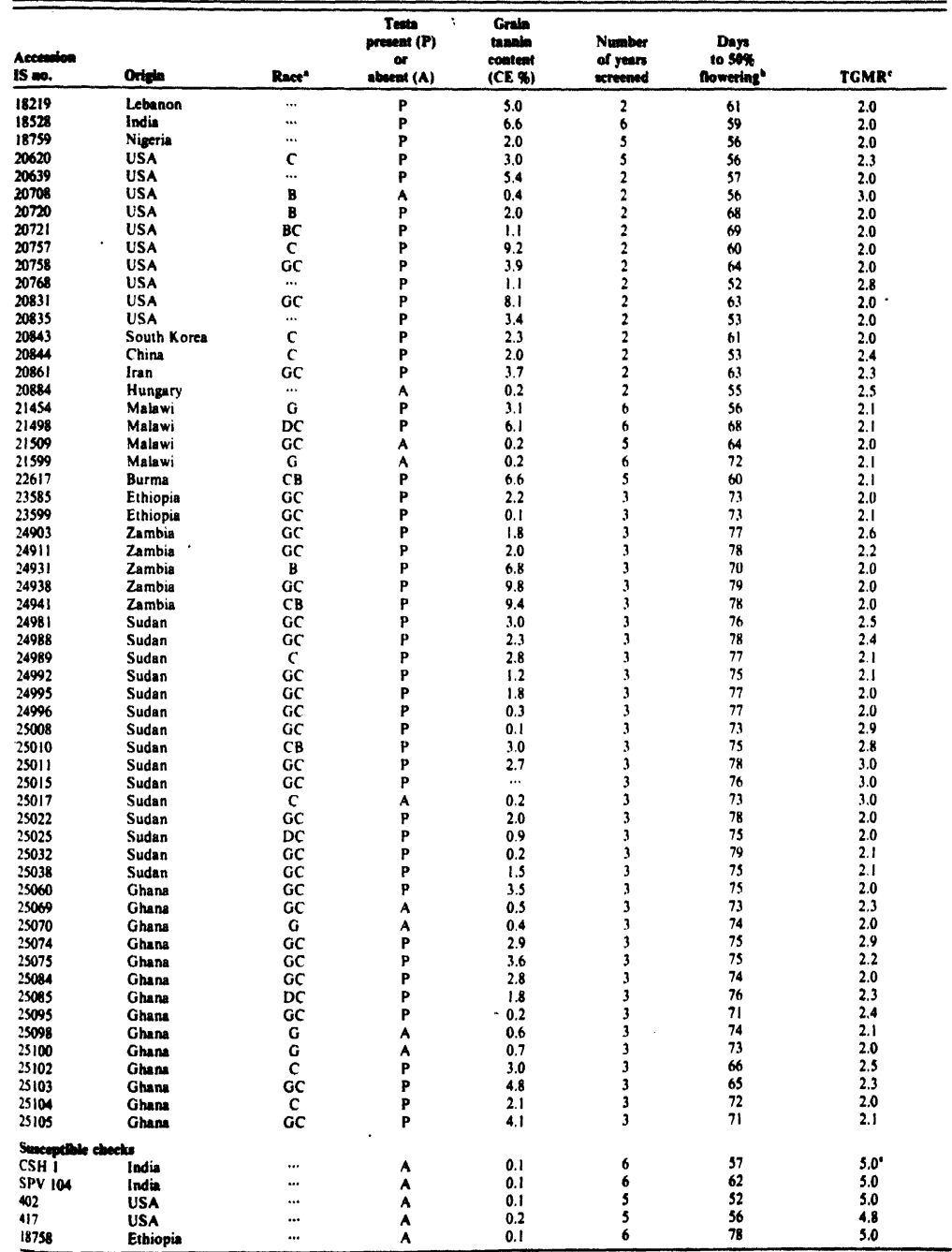

hown by the TGMRs of susceptible hecks (Table 2). Grain mold ratings of esistant accescions were 3 or below and erminntibn was greater than $70 \%$. lesiatance in these accestions was maintained for 2 wk after maturity, when panicles were harvested. Mold severity in susceptible sorghums usually increases after maturity, and the disease achieves cerious proportions when harventing is delayed after maturity in wet and humid conditions. All resistant lines except IS 25017 had colored pericarp. Under the fluoresence microscope, the testa layer was clearly identified as a dark brown 
layer, often with cross-walls, above the aleurone cell layer. The testa layer was absent in 14 resistant accessions. Tannin content in these 14, and in 10 other accessions with testa, was negligible (less than $1.0 \mathrm{CE} \%$ ). The range of tannin content in the resistant accessions was 0.1-10.7 CE \%.

The resistant accessions had wide morphological variability and diversity in taxonomic races (Table 2). The number of resistant accessions of the various races based on the classification by Harlan and de Wet (7) were: caudatum, 56; guinea, 11: bicolor, 3; durra, 2; kafir, 2; guinea-caudatum, 28; caudatum-bicolor, 20; durra-caudatum, 9; kafir-bicolor, 1; bicolor-caudatum. 1: durra-bicolor, 1; and guinea-bicolor, 1 . Twenty-one accessions have not been identified to race. The resistant accessions came from 25 countries, suggesting diversity in geographic origin.

Sources of grain mold resistance have been reported from the United States $(1,4-6)$, Senegal (3), and India $(9,11)$, including ICRISAT Center (13). The majority of the mold-resistant accessions reported from the United States have grain characteristics similar to the ones we report in this paper. Grains of these lines have colored pericarp; some have testa and some do not. Tannins in the testa layer have been reported to confer grain mold resistunce (8), but tannins are not always associated with grain mold resistance because several resistant accessions reported in this paper had negligible levels of tannin. Sorghums with colored grain usually have poor consumer acceptance in most parts of the world where the grain is used as nonbeverage food. However, the purpose of the present research was not to identify mold-resistant sorghums for direct introduction as cultivars, but to identify sources of mold resistance that can be further used in breeding programs. ICRISAT sorghum breeders are utilizing some of the resistant sources, particularly those without testa and with negligible tannin, to develop mold-resistant sorghums with good grain quality.

Although date are not presented in this paper, our screening results showed that contrary to previous reports in Indie $(9,11,13)$, the majority of the accessions had low levels of resistance, if any. The screening techniques used by Rao and Williams (13) and by us were similar (inoculation and bagging of panicles). but we harvested the panicles 10 days later than they did. Inoculation and bagging did not offer significant advantages over using untreated panicles. the method used by others $(9,11)$.

Length of the rainy season (mid-June to mid-October) at ICRISAT Center in relation to photoperiod sensitivity of the germ plasm limited screening of the majority of the accessions. The photoperiod-sensitive accessions fowered and filled grains after the rains ceased, thus escaping grain mold. Such lines can be screened at a location where grain filling and postmaturity stages coincide with grain mold-conducive environment.

Seed of the mold-resistant accessions described are available on request from the Genetic Resources Unit of ICRISAT.

\section{ACKNOWLEDGMENT}

We thank the Biochemistry Unit of ICRISAT for unalysis of grain samples for tannin content.

\section{LITERATURE CITED}

I. Castor, L. L., and Frederiksen, R. A. 1980 Fuserium and Curvularie grain molds in Texas. Pages 93-102 in: Sorghium Disesses. a World Review, International Crops Research Institute for the Semi-Arid Tropies, Pauncheru, India.

2. Curtis. D. L. 1968, The relation between the date of heading of Nigerian sorghums and the durntion of the frowing season. J. Appl. Eeol. 5:215-22\%.

3. Denis, J. C. and Girnerd, J. C. 1990. Factor affecting the development of soryhum grain molds in Senegal. Pages 144-153 in: Sorghum Dibeases, a World Review. Interational Crops Revenent Inatitute for the Semi-Arid Tropics. Patuncheru, Indis.

4. Giveck, J. A., and Rooney, L. W. 1976. Phyaical and chemical chanacterization of corghum lisea with retistance to grin deteriontion. (Abetr.) Cercal Foods World 21:436-437.

5. Glueck. J. A., and Rooney, L. W, 1990. Chemistry and structure of grain in relation to mold resiaunce. Pages 119-140 in: Sorghum Discases, \& World Review. Internutional Crops Research Institute for the Semi-Arid Tropics. Patancheru, India.

6. Gray. E., Lacefield, G. D., and Lowe, J. A. 1971. Head mold on grain sorehum. Plant Dis. Rep. 55:337.339.

7. Harlan, J. R., and de Wet, J. M. J. 1972 . A simplified classification of cultivated sorghum. Crop Sci. 12:172-176.

8. Harris, H. B., and Burns, R. E. 1973. Relationship between unnin content of sorghum grain and preharvest seed molding. Agrom J. 65:957-959.

9. Koteswara Rao, B., and Poornachandrudu, P. 1971. Lsolation of head molds and ascessment of moldy grains in certain sorghum varietien. Andhre Agric. J. 18:153-156.

10. Price. M. L., Scoyoc, S. V., and Butler, L. G. 1978. A critical evaluation of the vanillin reaction as an assay for tannin in sorghum grain. J. Agric. Food Chem. 26:1214-1218

11. Rana, B. S., Parameswarappa, R., Anahosur, K. H., Rao, V. J. M., Vasudeva Rao, M. J., and Reo, N. G. P. 1978. Breeding for multiple insect disease resiatance. All India Coordinated Sorghum Improvement Project Workshop. Dharwar, indis.

12. Rao, N. G. P., Vidyabhushanam, R., Rane, B. S., Rao, V. J. M., and Rao, M. J. V. 1980 Breeding sorghums for disease resintunce in Indis. Pages 430-433 in: Sorghum Diseases, World Revicw. International Crops Research Institute for the Semi-Arid Tropica, Patancheru, India.

13. Rmo, K. N., and Williams. R. J. 1960. Sereening for sorghum grain mold resistance at ICRISAT. Pages 103-108 in: Sorghum Diveases, a World Review. International Crops Research Intstitute for the Semi-Arid Tropics, Patancheru, India.

14. Williams, R. J., and Rao, K. N. 1981 . A review o sorghum grain moulds. Trop. Pest Manage. 27:200-211. 